E3S Web of Conferences 1, 03009 (2013)

DOI: $10.1051 / \mathrm{e} 3$ sconf/20130103009

(C) Owned by the authors, published by EDP Sciences, 2013

\title{
Mercury Studies around the Mediterranean Sea Basin: Ten years of Measurements and Modeling results
}

\author{
$\underline{\text { F. Sprovieri }}^{1}$, I.M. Hedgecock ${ }^{1}$ and N.Pirrone ${ }^{2}$ \\ ${ }^{1}$ CNR-IIA, Institute of Atmospheric Pollution Research, Italy; f.sprovieri@iia.cnr.it \\ ${ }^{2}$ CNR Institute of Atmospheric Pollution Research, Rome, Italy
}

\begin{abstract}
Only a few years ago the presence of Reactive Gaseous Mercury (RGM) was believed to be almost exclusively the result of anthropogenic emissions and that sustained high RGM concentrations in the MBL were not considered likely. During the past ten years, an in-depth investigation was carried out in the Marine Boundary Layer (MBL) of the Mediterranean Sea to quantify and possibly explain spatial and temporal patterns of $\mathrm{Hg}$-species concentrations. This paper provides an overview of modeling results and atmospheric measurements performed during several cruise campaigns performed aboard the Research Vessel (RV) URANIA of the CNR over the Mediterranean sea basin. RGM concentrations have been modelled using a photochemical box model of the MBL and compared to measured data obtained during the research cruises. The comparison results supports the hypothesis that there are daytime mercury oxidation reactions occurring which have not yet been identified. Major findings of key studies carried out during ten years of ship-borne activities have been highlighted.
\end{abstract}

Keywords: Reactive Gaseous Mercury, MBL, AMCOTS box Model, MEDOCEANOR

\section{Introduction}

Mercury $(\mathrm{Hg})$ is released into the atmosphere both by anthropogenic activities (i.e., fossil fuel combustion), and naturally, (i.e., soil outgassing, volcanoes and evasion from the sea) (Pirrone et al., 2001; 2010). One of the more troublesome questions in recent years has been to quantify the effects of re-emission of previously deposited $\mathrm{Hg}$ on the overall distribution, concentration and speciation of atmospheric $\mathrm{Hg}$. In the troposphere, $\mathrm{Hg}$ exists predominantly as gaseous elemental mercury (Hg0; GEM), Reactive Gaseous Mercury (RGM, HgII) and fine particle-bound $\mathrm{Hg}$ (Hgp). Conversions between different $\mathrm{Hg}$ forms add complexity to the ability to understand $\mathrm{Hg}$ chemistry and transport on the local, regional, and global scales. The deposition of atmospheric $\mathrm{Hg}$ depends on its chemical speciation; $\mathrm{Hg} 0$ is relatively inert under atmospheric conditions, only slightly soluble and also quite volatile, whereas $\mathrm{HgII}$, such as $\mathrm{HgO}, \mathrm{HgCl} 2$ and $\mathrm{HgBr} 2$, is both soluble and involatile. Thus $\mathrm{HgII}$ is efficiently scavenged and deposited to receptor bodies. Consequently, a complex mixture of chemical, physical and meteorological parameters control the fate of atmospheric $\mathrm{Hg}$. The importance of $\mathrm{Hg}$ exchange processes between the atmosphere and surface waters has been highlighted in recent studies related to the Mediterranean region which is also rather particular from the point of view of mercury. The area contains $65 \%$ of the world's cinnabar deposits that runs from southern Spain to Tuscany in Italy and up into Slovenia. In addition, the fact that the Mediterranean is a semi-closed sea bordered by numerous industrialized nations, with a large population living close to the coast, has led to concerns that pollutants and contaminants could build up within the Basin and affect wildlife. The lack of knowledge of the magnitude of the air-sea exchange mechanisms is one of the main factors affecting the overall uncertainty associated with the assessment of net fluxes of $\mathrm{Hg}$ between the atmospheric and marine environments in the Mediterranean region (Sprovieri et al., 2003; Hedgecock and Pirrone, 2004; Horvat et al., 2001, 2003; Gardfeldt et al., 2003; Kotnik et al., 2007; Sprovieri and Pirrone, 2008; Pirrone et al., 2008). The aim of this work is to provide a review of measurements and modeling results obtained during the last ten years of studies carried out in the western and eastern sector of the Mediterranean Sea Mediterranean sea basin on board the Italian Research Vessel URANIA (CNR). 


\section{Results and Discussion}

The Mediterranean sea is an enclosed basin connected to the Atlantic Ocean by the narrow strait of Gibraltar through which the exchange of water flow is driven by salinity and heat gradient. Water loss by evaporation exceeds the input by precipitation because of intense solar radiation over several months of the year, its high temperature and extended periods with little or no precipitation also contribute to distinguishing the Mediterranean basin from other seas. The sampling campaigns were performed from yr 2000 during different seasons and covered both the western and eastern sectors of the Mediterranean basin. Field measurements performed using new $\mathrm{Hg}$ sampling techniques at coastal Mediterranean sites during the past EU projects (i.e., MAMCS-MOE, MERCYMS) along with advances in modeling techniques have shown and confirmed that the mercury chemistry particularly in the MBL is more complex than was once thought and becomes clear that $\mathrm{Hg}$ is not simply transported within air masses maintaining passively its background concentrations but it is partially involved in chemical and physical processes making its distribution between volatile and less volatile species. A comparison between the work conducted during MAMCS and the first MED-OCEANOR campaign in Summer 2000 suggests that $\mathrm{Hg} 0$ concentrations observed over the water were higher than those observed at MAMCS coastal sites. The higher values could be related to $\mathrm{Hg} 0$ evasion from the seawater due to chemical reduction of oxidized mercury in the water column, suggesting that the surface seawater is an important source of $\mathrm{Hg}$ released (re-emitted) in the global atmosphere. The influence of sunlight on the reduction of $\mathrm{HgII}$ in the aqueous phase has been observed by many scientists and was investigated during Atlantic and Pacific Ocean cruises (Mason et al., 2001; Laurier et al., 2003). One feature which all the MBL measurements of RGM have in common is a diurnal variation with a maximum $\mathrm{Hg}(\mathrm{g}) \mathrm{II}$ concentration which coincides with the solar irradiation maximum, indicative of photolytically produced oxidants being responsible for the gas phase oxidation of $\mathrm{HgO}$ to $\mathrm{HgII}$. It is clear that RGM measurements will always contain a contribution from both (a) "in situ" production and (b) atmospheric transport from emission sources on the mainland and it is not possible to distinguish between them, therefore not possible to draw conclusions regarding, for instance, the influence of atmospheric transport on deposition at a given site. However, considering the short lifetime of the RGM in the MBL, primarily driven by the combination of high humidity and high Henry's Law constant, the relative contribution of atmospheric transport should not be significant; on the other hand, the clear diurnal fluctuation of RGM concentration with the minimum during the night, could exclude the possibility that the high RGM values is related to the contribution due to transport from anthropogenic sources. In addition, the fact that the model used by Hedgecock et al., 2001 and
2003 reproduce the daily fluctuation in RGM values and the nocturnal measured and modelled minima coincide (Hedgecock et al., 2001; 2003) would also indicate that transport was not a major factor in determining the RGM concentration. Firstly, the most important reactions involved in the conversion of $\mathrm{HgO}$ to $\mathrm{HgII}$ were believed to be the reactions, both in the aqueous and the gas phase, with O3. Later, the publication of the rate constant for the gas phase reaction between $\mathrm{Hg} 0$ and $\mathrm{OH}$ highlights that this assumption needs to be reviewed, and the atmospheric lifetime of $\mathrm{Hg} 0$, previously assumed to be of the order of six months to $1 \mathrm{yr}$, based on the rate of the gas phase reaction of $\mathrm{Hg}$ and $\mathrm{O} 3$, has to be reduced, probably to around 3 months. The importance of $\mathrm{O} 3$ above other oxidants has been further called into question in specific cases such as the remote marine boundary layer (MBL) (Hedgecock and Pirrone, 2001) where the ratio of the $\mathrm{H} 2 \mathrm{O} 2$ concentration to the $\mathrm{O} 3$ concentration is higher than that found in the continental boundary layer, and where modeling studies have suggested that the role of $\mathrm{H} 2 \mathrm{O} 2$ in $\mathrm{Hg} 0$ oxidation is as important as that of O3. The first modeling studies (Pirrone et al., 2000; Hedgecock and Pirrone, 2001) suggested that in the MBL gas phase oxidation is much more important than aqueous phase and that RGM was produced in the MBL througout the out-gassing of $\mathrm{HgCl} 2$ from aerosol particles. $\mathrm{HgCl} 2$ is, in fact, indirectly produced by the gas phase oxidation of $\mathrm{Hg} 0$ and $\mathrm{OH}$ (Hedgecock et al., 2001) which leads to the production of $\mathrm{HgO}$; the latter due to its efficient scavenging by the aerosol particles is transferred to the aqueous phase which reacts with $\mathrm{H}+$ ions producing $\mathrm{HgII}$. Indeed the sea-salt aerosol scavenges $\mathrm{HgO}$ from the gas phase and cycles mercury (reemission) to $\mathrm{HgCl} 2$. However, the midday maxima observed in Hedgecock $\mathrm{t}$ al., 2003 are underestimated by a factor of two. The model's inability to reproduce the daytime maxima should be due to: a) Reaction or reactions which proceed much faster during the day than the night and thus a reactant which is far more abundant by day than by night; b)The other possibility that comes to mind is a reactant whose concentration is closely linked to daytime photochemistry, either in that it is the product of a photolytic process or is the product of a reaction involving a photolysis product [i.e., Halogen (Br) containing compounds]. Highly time resolved $\mathrm{Hg}$ measurements performed in the Arctic and in Antarctica (Sprovieri et al., 2005a,b; Dommergue et al., 2010; Sprovieri et al., 2010) showed the important role that halogen chemistry may play in mercury chemistry. Modelling studies have shown that $\mathrm{BrO}$ can play a role in $\mathrm{O} 3$ destruction in the remote MBL. The inclusion within the AMOCOTS box Model of the reaction of $\mathrm{Hg}$ with $\mathrm{Br}$ (Hedgecock et al., 2005; Sprovieri et al., 2010) produces a distinct improvement in the model estimation of maximum RGM values compared to Hedgecock et al. (2003). Measurements of atmospheric $\mathrm{Hg}$ species were conducted across the Adriatic sea during two cruise campaigns during autumn 2004 and summer 2005. The generally calm sea and stable atmospheric conditions 
during summer 2005, with no rain permit the constrained version of the AMCOTS model to be used in an attempt to simulate the daily production of RGM in the MBL. The results show that although the in-situ production of HgII occurs in the MBL, the exact chemical mechanism responsible is difficult to determine. However given the high O3 concentrations encountered during 2005 campaign it seems clear that if $\mathrm{Hg} 0$ does react with $\mathrm{O} 3$, it does not produce gas phase HgII. Equally, the reaction between $\mathrm{Hg} 0$ and $\mathrm{OH}$ if it occurs, does not contribute appreciably to HgII production. The chemical mechanism employed for the summer 2005 results was used to re-run the simulations for the summer 2000 oceanographic campaign described in Sprovieri et al. (2003) and modelled in Hedgecock et al. (2003, 2005). The comparison between the simulated and observed RGM concentrations proved to be similar to those previously published. Thus the mechanism employed for Sprovieri et al., 2010 which covers only the Adriatic can also reproduce reasonably the data from the summer 2000 oceanographic campaign which covered a far larger of the Mediterranean.

The modeled monthly amounts of $\mathrm{Hg}$ deposited to the waters of the Mediterranean Sea by dry and wet deposition processes has been calculated by Hedgecock et al. (2006) using the MECAWEx model highlighting that the amount of $\mathrm{Hg}$ emitted from the surface waters is actually far greater than that deposited making the Mediterranean Sea a net source which contributes roughly 70 tons of $\mathrm{Hg}$ per annum to the atmosphere. These results are in agreement with those obtained by Andersson et al. (2007) using the gas exchange model developed by Nightingale et al. (2002) including measurement data from cruise campaigns performed in the Mediterranean sea during Summer 2000, 2003, Spring and Fall 2004. The yearly evasion estimated by Andersson et al. (2007) from the Mediterranean Sea surface was to 77 tons.

\section{Acknowledgements}

These works are part of the past projects funded by the EU Commission in the FP4 and FP5 (MAMCS-MOE, MERCYMS) and are part of the MEDOCEANOR project funded by the Italian National Research Council (CNR).

\section{References}

Andersson ME, Gardfeldt K, Wangberg I, Sprovieri F, Pirrone N, Lindqvist O. Seasonal and daily variation of mercury evasion at coastal and off shore sites from the Mediterranean Sea. Mar Chem 2007; 104:214-226.

Dommergue, A., Sprovieri, F., Pirrone, N., Ebinghaus, R., Brooks, S., Courteaud, J., and Ferrari, C. P.: Overview of mercury measurements in the Antarctic troposphere, Atmos. Chem. Phys., 10, 10(7), 3309 (2010)
Gårdfeldt, K., Sommar, J., Ferrara, R., Ceccarini, C., Lanzillotta, E., Munthe, J., Wängberg, I., Lindqvist, O., Pirrone, N., Sprovieri, F., 2003. Evasion of mercury from coastal and open waters of the Atlantic Ocean and the Mediterranean Sea. Atmospheric Environment 37 (1), 73-84.

Hedgecock I, Pirrone N. Mercury and Photochemistry in the Marine Boundary Layer - Modelling Studies suggest the in situ Production of Reactive Gas Phase Mercury. Atmos Environ 2001; 35:30553062.

Hedgecock I, Pirrone N, Sprovieri F, Pesenti E. Reactive Gaseous Mercury in the Marine Boundary Layer: Modeling and Experimental Evidence of its Formation in the Mediterranean. Atmos Environ 2003; 37/S1:41-50.

Hedgecock IM, Pirrone N. Chasing Quicksilver: Modeling the Atmospheric Lifetime of $\mathrm{HgO}(\mathrm{g})$ in the Marine Boundary Layer at Various Latitudes. Environ Sci Technol 2004; 38(1):69-76.

Hedgecock, I. M., Trunfio, G. A., Pirrone, N., and Sprovieri, F.: Mercury chemistry in the MBL: Mediterranean case and sensitivity studies using the AMCOTS (Atmospheric Mercury Chemistry over the Sea) model, Atmos. Environ., 39, 7217-7230, 2005.

Hedgecock IM, Pirrone N, Sprovieri F. Chasing quicksilver northward: mercury chemistry in the Arctic troposphere. Environ Chem 2008; 5:31-134.

Horvat M, Kotnik J, Fajon V, Logar M, Zvonaric T, Pirrone N. Speciation of Mercury in Surface and Deep-Sea waters in the Mediterranean Sea. Atmos Environ 2003; 37/S1:93-108.

Kotnik J, Horvat M, Tessier E, Ogrinc N, Monperrus M, Amouroux D, Fajon V, Gibicar D, Zizek S, Sprovieri F, Pirrone N. Mercury speciation in surface and deep waters of the Mediterranean Sea. Mar Chem 2007; 28:13-30.

Lindberg, S., Bullock, R., Ebinghaus, R., Engstrom, D., Feng, X. B., Fitzgerald, W., Pirrone, N., Prestbo, E., and Seigneur, C.: A synthesis of progress and uncertainties in attributing the sources of mercury in deposition, Ambio, 36(1), 19-32, 2007.

Mason RP, Lawson NM, Sheu GR. Mercury in the Atlantic Ocean: factors controlling air-sea exchange of mercury and its distribution in the upper waters 2001; Deep-Sea Res II; 48:2829-2853.

Nightingale P D, Malin G, Law CS, Watson AJ, Liss PS, Liddicoat MI, Boutin J, Upstill-Goddard RC. In situ evaluation of air-sea gas exchange parameterizations using novel conservative and volatile tracers Global Biogeochem Cycles 2000; 28(1):373-387.

Pacyna, E. G., Pacyna, J. M., Steenhuisen, F., and Wilson, S.: Global Anthropogenic Mercury Emission Inventory for 2000, Atmos. Environ., 40, 4048-4063, 2006.

Pirrone, N., Costa, P., Pacyna, J. M., and Ferrara, R.: Mercury emissions to the atmosphere from natural 
and anthropogenic sources in the Mediterranean region, Atmos. Environ., 35, 2997-3006, 2001.

Pirrone, N., Hedgecock, I.M., Sprovieri, F.: New Direction: Atmospheric Mercury, easy to spot and hard to pin down: impasse? Atmosperic Environment 42(36), 8549 - 8551 (2008)

Pirrone, N., Cinnirella, S., Feng, X., Finkelman, R. B., Friedli, H. R., Leaner, J., Mason, R., Mukherjee, A. B., Stracher, G. B., Streets, D. G., and Telmer, K.: Global mercury emissions to the atmosphere from anthropogenic and natural sources, Atmos. Chem. Phys., 10, 5951-5964, doi:10.5194/acp-10-5951 2010, 2010.

Sprovieri F, Pirrone N, Gardfeldt 694 K, Sommar J. Atmospheric Mercury Speciation in the Marine Boundary Layer along $6000 \mathrm{~km}$ Cruise path over the Mediterranean Sea. Atmos Environ 2003; 37(S1): 63-71.

Sprovieri, F., Pirrone, N., Landis, M., and Stevens, R. K.: Oxidation of gaseous elemental mercury to gaseous divalent mercury during 2003 polar sunrise at $\mathrm{Ny}$ Alesund, Environ. Sci. Technol., 39, 9156-9165, 2005a.

Sprovieri, F., Pirrone, N., Landis, M., and Stevens, R. K.: Atmospheric mercury behaviour at different altitudes at Ny Alesund during Spring 2003, Atmos. Environ., 39, 7646-7656, 2005 b.

Sprovieri F, Pirrone N. Spatial and temporal distribution of atmospheric mercury species over the Adriatic Sea. Environ Fluid Mech 2008; 28:117-128.

Sprovieri, F., Hedgecock, I. M., and Pirrone, N.: An investigation of the origins of reactive gaseous mercury in the Mediterranean marine boundary layer, Atmos. Chem. Phys., 10, 3985-3997, doi:10.5194/acp-10-3985-2010, 2010.

Sprovieri, F., Pirrone, N., Ebinghaus, R., Kock, H., and Dommergue, A. (2010) A review of worldwide atmospheric mercury measurements. Atmos. Chem. Phys. 10, 8245-8265. 